\title{
Implementasi Ruqyah Syar'iyah sebagai Alternatif Psikoterapi dalam Kajian Psikologi Islam
}

\author{
Arni \\ Universitas Islam Negeri (UIN) Antasari Banjarmasin
}

\begin{abstract}
Ruqyah Syar'iyyah is an Islamic healing that uses recitation of the holy Koran, dhikr and prayers. Diseases that can be cured through ruqyah syar'iyyah with the permission of Allah are physical and mental illnesses or physical and spiritual diseases, in other terms are physical or psychological illnesses. The basis for this Islamic healing is found in the Koran and the hadiths of the prophet. Even though there is a basis, the attitude of the Muslims towards ruqyah is divided into three parts, namely ifrath, tafrith and mu'tadil. For patients who suffer from the law, asking for meruqyah is only permissible, while peruqyah for circumcision is to help people who ask for help. The scholars agree that the use of this ruqyah with the holy Koran verses and believe that humans are only as intermediaries, the problem of healing is the permission of Allah SWT. Rasulullah practiced three types of divine medicine, namely Ruqyah Sayar'iyyah, Thabi'iyyah and Al-Jam'u baina huma. These three are summarized in a system called Thibbun Nabawi. This Ruqyah with Allah's permission makes a sick person become healthy, or a person who was originally unconscious becomes conscious. In the past, in our area it was known as batatamba, which is to treat illnesses to healers who use the holy Koran, dhikr and prayers. Now the term ruqyah syar'iyyah is popular. Nowadays, ruqyah is practiced or practiced on TV, Youtobe and in certain places that provide official medical treatment. Apart from ruqyah for sick people, there are also people who are healthy, conscious and suspect that they have jinn, so they ask for diruqyah. In the end, he was unconscious as if he was possessed by spirits, and some even vomited and urinated after being recited by the peruqyah recitation of the ruqyah. This situation collides with the aim of ruqyah which is to heal a sick person or awaken an unconscious person. Not a person who is conscious of being forced to become unconscious (a kind of trance). If he died at this time, of course he would forget Allah.
\end{abstract}

Keyword: Ruqyah Syar'iyyah; Alternative Therapy; Islamic Psychology

\begin{abstract}
Abstrak
Ruqyah Syar'iyyah adalah pengobatan islami yang menggunakan bacaan ayat-ayat suci Alquran, zikir dan doa. Penyakit yang bisa disembuhkan lewat ruqyah syar'iyyah dengan izin Allah adalah penyakit lahir maupun batin atau penyakit jasmani atau rohani, dengan istilah lain adalah penyakit fisik ataupun psikis. Dasar adanya penyembuhan secara islami ini terdapat dalam Alquran dan hadis nabi. Walaupun ada dasarnya, sikap umat Islam terhadap ruqyah ini terbagai tiga yaitu ifrath, tafrith dan mu'tadil. Bagi pasien penderita hukumnya minta diruqyah hanya mubah, sedangkan peruqyah sunat hukumnya menolong orang yang minta bantuan. Para ulama sepakat penggunaan ruqyah ini dengan ayat suci Alquran dan yakin
\end{abstract}


bahwa manusia hanya sebagai perantara, masalah kesembuhan adanya izin dari Allah swt. Rasulullah mempraktikan tiga jenis pengobatan ilahiyah yaitu Ruqyah Sayar'iyyah, Thabi'iyyah dan Al-Jam'u baina huma Ketiganya ini dirangkum dalam satu sistem yang disebut Thibbun Nabawi. Ruqyah ini dengan izin Allah membuat orang yang sakit menjadi sehat, atau orang yang asalnya tidak sadarkan diri menjadi sadar. Dulu di daerah kita ini dikenal dengan istilah batatamba yaitu mengobati penyakit kepada tabib yang menggunakan ayat suci Alquran, zikir dan doa. Sekarang istilah ruqyah syar'iyyah yang populer. Dewasa ini ruqyah banyak dipragakan atau dipraktikan di TV, Youtobe serta di tempat-tempat tertentu yang melayani pengobatan secara resmi. Di samping ruqyah untuk orang yang sakit, juga dalam kenyataan ada orang yang sehat, dalam keadaan sadar dan menduga dalam dirinya ada jin sehingga dia minta diruqyah. Pada akhirnya dia tidak sadarkan diri semacam kerasukan mahluk halus, bahkan ada yang sampai muntah-muntah dan terkencing-kencing setelah dibacakan bacaan ruqyah oleh peruqyah. Keadaan ini berbenturan dengan tujuan ruqyah yang untuk menyembuhkan orang yang sakit atau menyadarkan orang yang tidak sadarkan diri,. Bukan orang yang sadar diruqyah menjadi tidak sadarkan diri (semacam kesurupan). Kalau dia meninggal dunia di saat ini tentu lupa Allah.

Kata Kunci : Ruqyah Syar'iyah; Alternatif Terapi; Psikologi Islam

Di antara ajaran Islam yang berkenaan dengan penyembuhan penyakit adalah ruqyah syar'iyyah. Kaum muslimin meyakini bahwa agama Islam yang paling sempurna dan relefan di setiap tempat dan zaman. Sehingga tidak ada satu hal apapun, dimanapun, dan kapanpun yang luput dari ajaran-ajaran Islam, termasuk dalam kaitannya pengobatan atau penyembuhan. Antusias masyarakat Islam dewasa ini terhadap ruqyah sebagai alternatif pengobatan, merupakan satu hal yang patut untuk disyukuri. Walaupun motif dan tujuan mereka dalam memilih ruqyah sebagai terapi pengobatan ini beraneka ragam. Namun paling tidak, hal itu telah memberikan satu sinyal akan kesadaran sebagian umat ini terhadap tuntunan agamanya. Mungkin tidak sedikit di antara kita, yang tidak mengerti atau tidak menyadari, bahwa ruqyah adalah salah satu terapi pengobatan syar'i yang bersumber dari Allah dan Rasul-Nya, yaitu Alquran dan As Sunnah, sehingga ruqyah merupakan ibadah, dan kebenarannya telah dibuktikan oleh generasi pendahulu umat ini.

Psikoterapi Islam merupakan tahapan proses penyembuhan dan pengobatan suatu penyakit mental maupun fisik dengan melalui bimbingan Al-Qur'an dan As-Sunnah Nabi SAW dan ini sudah diterapkan dalam kalangan Muslimin dengan sebutan ruqyah syar'iyyah dan 
sudah diimplementasikan di berbagai daerah di Indonesia. Menurutnya, pada hakikatnya ruqyah syar'iyyah merupakan metode pengobatan Rasulullah SAW. Salah satu penyakit mental yang dapat disembuhkan dengan terapi ruqyah syar'iyyah adalah gangguan jiwa. Salah satu penyebab dari gangguan jiwa bisa saja akibat pengaruh ilmu sihir.

Ruqyah adalah terapi pengobatan terhadap mereka yang mengalami sakit jasmani dan rohani ataupun disebabkan adanya pengaruh jin atau disebut dengan penyakit 'ain. Penyakit 'ain ini disebut juga dengan istilah "mata jahat" yaitu penyakit akibat gangguan jin atau pun santet yang dibuat oleh manusia yang dibantu jin. Rasulullah bersabda:

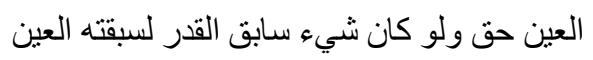

"Mata jahat itu nyata. Seandainya ada sesuatu yang dapat mendahului takdir, maka sesuatu itu adalah mata jahat"

Aisyah mengatakan sebagaimana diriwayatkan dalam shahih Bukhari Muslim Rasululllah menyuruhku agar kami menggunakan ruqyah untuk melawan mata jahat. Mata jahat ini ada 2 jenis yaitu yang berkaitan dengan manusia ('ain insi) dan yang berkaitan dengan jin ('ain jinni) (Ibnu Qayyim Al-Jauziyah, 2013). Walaupun ruqyah syar'iyyah ini sudah dikenal luas namun sikap umat Islam terhadap ruqyah ini ada tiga macam yakni: Pertama sikap Ifrath yaitu berlebih-lebihan dalam memaknai ruqyah sebagai obat, sehingga meninggalkan pengobatan secara medis. Kedua sikap Tafrith yaitu menolak sama sekali keberadaan ruqyah sebagai terapi untuk mengatasi gangguan atau penyakit. Ketiga sikap Mu'tadil yaitu mempertimbangkan kecocokan penyakit dengan obat. Jika memang gangguan atau penyakitnya akibat sihir dan kemasukan jin, maka harus ditempuh melalui cara ruqyah syar'iyyah. Tetapi jika penyakitnya murni medis, maka harus diatasi dengan terapi medis, termasuk yang direkomendasikan Rasulullah seperti bekam dan obat-obatan natural atau adwiyah thabi'iyyah (Tambusai, 2010).

Ditinjau dari sudut penggunaan dan sarana yang digunakan, maka ruqyah dibagi menjadi dua kategori yaitu ruqyah syar'iyyah (mantera yang dibolehkan) dan ruqyah syirkiyyah ( mantera yang mengandung syirik yang diharamkan). Telah banyak kajian terdahulu yang membahas mengenai ruqyah secara general, seperti kajian yang dilakukan oleh Susanto (2014) 
yang menyebutkan bahwa dakwah melalui layanan psikoterapi ruqyah dapat menyembuhkan pasien penderita kesurupan. Menurutnya pengaruh terapi ruqyah terhadap perubahan perilaku penderita kesurupan tersebut dapat digolongkan sebagai psikoterapi Islam. Selain itu, juga ada kajian yang dilakukan oleh Ahmad \& Ariffin (2014) yang mengkaji mengenai Ruqyah Berasaskan Al-Quran, dalam kajiannya dia memberikan Analisis Signifikannya ruqyah Dalam perwatan Penyakit. Menurutnya ada faktor-faktor penting mengapa ayat-ayat al-Quran atau doa-doa tertentu dapat berpengaruh sebagai ruqyah dalam membantu mengobati penyakit yang dihadapi pasien. Selain itu juga ada kajian yang dilakukan oleh Afiyatin (2019) mengenai Ruqyah Sebagai Pengobatan Berbasis Spiritual Untuk Mengatasi Kesurupan. Menurutnya spiritual memiliki peran yang signifikan dalam proses ruqyah yang dilakukan untuk mengatasi pasien yang menderita penyakit rohani berupa kesurupan.

Tutut (2020) juga melakukan kajian terkait ruqyah syariyyah ini dalam kajiannya metode ruqyah dalam pemulihan pasien skizofrenia. Berdasarkan hasil temuannya diketahui bahwa metode Ruqyah yang dilakukan berdampak positif terhadap kejiwaan pasien, dalam pemulihannya, pasien gangguan jiwa Skizofrenia mengalami pemulihan yang sangat cepat dan menurut pasien yang telah dilakukan Ruqyah bahwasanya keadaan yang dialami sudah lebih baik dari sebelumnya dan merasakan perasaan yang nyaman,tenang, dan gangguan-gangguan yang di alami nya dulu sedikit demi sedikit hilang karna metode ruqyah butuh proses berulang-ulang tidak cukup hanya sekali dalam membantu proses pemulihannya.dikarnakan pasien gangguan jiwa tidak hanya diberikan pengobatan melalui medis saja tetapi butuh nya resep kerohanian keimanan dari Allah sesuai dengan syariat Islam. Adapun pembahasan dalam kajian yang akan dipaparkan dalam tulisan ini lebih fokus kepada pembahasan secara komprehensif mengenai implementasi atau tata cara yang tepat dalam melakukan ruqyah syar'iyah sebagai sebuah alternatif dalam penyembuhan dalam psikoterapi tersebut, sehingga berdasarkan hasil kajian ini, para pembaca dapat memahami dengan rinci bagaimana tahapan dan tata cara mengimpelemnetasikan ruqyah sebagai alternatif psikoterapi tersebut. 


\section{Metode}

Dalam kajian ini penulis telah mengambil metode literature review sebagai pijakan utama dalam pengumpulan data. Menurut Sugiyono (2010) ini adalah teknik yang bisa diambil peneliti jika peneliti bermaksud melakukan sebuah studi pendahuluan bertujuan untuk menemukan pokok dari permasalahan yang akan di teliti. Ada dua alasan mendasar mengapa peneliti memilih literature review sebagai metoode dalam kajian ini, pertama peneliti bermaksud mengumpulkan data terkait ruqyah syar'iyah dalam kajian psikoterapi dan pandangan Islam mengenai salah satu alternatif penyembuhan pasien yang mengalami gangguan atau sakit baik secara fisik maupun mental, hal ini dimaksudkan untuk mendapatkan atau menggali informasi yang lebih dalam dan mendetail dengan berbagai macam bentuk dokumentasi dari penelitian terdahulu terkait ruqyah syar'iyah.

Arikunto (2010) juga menyebutkan bahwa literature review dapat digunakan untuk mengumpulkan data terkait hal hal atau variabel variabel berupa buku buku, transkrip, catatan, majalah, surat kabar, pasasti, agenda, notulen rapat dan sebagainya. Penulis memilih untuk melakukan studi melalui dokumentasi karena dapat memperkuat data serta bukti yang ada serta dapat melengkapi hasil penelitian dari literature review yang lebih akurat dan terpercaya. Dalam kajian ini literatur review dijadikan sebagai sumber data primer, yakni berasal dari sumber-sumber yang mendukung terkait dengan buku-buku, artikel, jurnal penelitian, baik itu berupa catatan, laporan, majalah, berita, situs web dan lain-lain serta data-data yang mendukung. Adapun sumber utama dalam kajian ini adalah karya Ummu Abdillah Hanien Az-Zarqaa', Terapi Pengobatan dengan Ruqyah Syar'iyah, Nasir bin Muhammad Abdurrahim, Inilah Jampi-Jampi (Ruqyah) Yang Diajarkan Rasulullah SAW, Musdar Bustamam Tambusai, Halal Haram RUQYAH, Musdar Bustamam Tambusai, Buku Pintar Jin, Setan dan Ruqyah Syariyyah, dan karya Muhammad Sakhowi el-Quds, dkk, Pengobatan Dengan Al-Qur'an, dan Arwani Amin, Jalan Menuju Sehat Jasmani \& Rohani Melalui Ruqyah Syar'iyah. Selain itu juga dilengkapi oleh beberapa kajian dalam jurnal yang dianggap relevan dengan kajian ini. Analisis data dilakukan dalam tiga tahapan, yakni reduksi data, penyajian data, dan verifikasi yang ditutup dengan memberikan kesimpulan. 


\section{Hasil dan Pembahasan}

Secara etimologi, ruqyah berarti permohonan perlindungan, atau ayat-ayat, zikir-dzikir dan doa-doa yang dibacakan kepada orang yang sakit. Sedangkan menurut terminologi syariat, ruqyah berarti bacaan-bacaan untuk pengobatan yang syar'i (berdasarkan nash-nash yang pasti dan shahih yang terdapat dalam Alquran dan As Sunnah) sesuai dengan ketentuan-ketentuan serta tata cara yang telah disepakati oleh ulama (Az-Zarqaa', 2005). Ruqyah syar'iyyah yaitu ruqyah (jampi-jampi) yang dilakukan dengan menggunakan ayat-ayat Alquran, do'a dan zikir yang ma'tsur yang diajarkan sendiri oleh Rasulullah saw., atau amalan para sahabat yang disetujui oleh Rasulullah (Abdurrahim, 2010). Rasulullah telah mempraktikan tiga jenis pengobatan yaitu: Ruqyah Syar'iyyah, Thabi'iyyah (mengkunsumsi madu, kurma, habbastus sauda) dan Al- Jam'u baina huma (mengkombinasikan keduanya). Semuanya terangkum dalam satu sistem yang disebut Thibbun Nabawi (Tambusai, 2010).

Manan (1991) menyebutkan pengertian ruqyah secara umum adalah kalimat atau susunan kata-kata baik dapat dimengerti atau tidak, yang dipercaya dapat memiliki daya gaib (bertuah), yakni dapat menarik keuntungan dan menolak kemudaratan. Bahkan Ibnu Al-Atsir dalam berkata sebagai dinukil Ibnu Manzhur, ruqyah adalah bacaan perlindungan yang dibacakan kepada orang yang sakit seperti demam, kesurupan dan penyakit-penyakit lain. Sedangkan Syaikh Al-Bani mengatakan bahwa ruqyah adalah bacaan yang dibaca untuk meminta kesembuhan yang berasal dari Alquran dan hadist yang shahih. Dr. Yusuf AlQaradhawi mendefinisikan ruqyah dengan definisi yang tidak jauh berbeda. Beliau mengatakan, "Ar-Ruqaa merupakan bentuk jama' (plural) dari ruqyah, yaitu do'a perlindungan yang dibacakan kepada orang yang sakit seperti demam, kesurupan, digigit ular atau disengat kalajengking dan sebagainya, sebagaimana dibacakan pula kepada orang yang sakit disebabkan ain (Tambusai, 2010). Menurut penulis, ruqyah adalah bacaan dari ayat Alquran, zikir atau doa, yang dipercaya punya kekuatan gaib untuk pengobatan dan pembentengan (pagar gaib) serta untuk mencapai suatu keberhasilan.

Ruqyah syar'iyyah seharusnya mendapatkan tempat mulia di mata masyarakat. Citra ruqyah syar'iyyah sebagai terapi solusi untuk mengatasi gangguan jin dan sihir memang benar, tetapi seorang peruqyah jangan sampai dicap sebagai "pengusir jin" saja atau lebih gawat 
disamakan dengan "pemburu hantu" (Tambusai, 2013). Peruqyah hanya menolong orang dalam mengobati penyakit lahir dan batin ataupun akibat gangguan jin.

Hukum menggunakan ruqyah untuk mengobati penyakit adalah mubah (boleh). Bahkan syariat menganjurkannya. Berdasarkan nash-nash tekstual dalam Al Qur'an dan As-Sunnah. Syaikh Muhammad bin Shalih Al 'Utsaimin rahimahullah- menjelaskan pula: ruqyah, bagi orang yang melakukannya (untuk orang lain) hukumnya adalah sunnah, karena tindakan tersebut merupakan wujud ihsan (perbuatan baik) bagi orang yang di ruqyah. Sedangkan bagi orang yang (meminta) diruqyah, maka hukumnya boleh (Az-Zarqaa', 2005).

\section{Dasar Implementasi Ruqyah dalam Ajaran Islam}

Menurut Hanifah (2015) dalam kehidupan ini manusia tentu pernah mengalami masalah yang datang silih berganti, bahkan terkadang masalah yang datang sampai tumpang tindih. Menurutnya masalah yang datang bertubi-tubi ini tentu dapat mengganggu kejiwaaan dan fisik seseorang. Seiring dihadapkannya pada masalah-masalah yang pelik, tidak menutup kemungkinan hal tersebut akan mengganggu kestabilan mental seseorang sehingga diperlukannya pemulihan kesehatan mental. Salah satu caranya adalah dengan terapi ruqyah syar'iyyah.

Dalam kajian yang penulis lakukan, ditemukan adanya banyak dalil yang menjadi dasar dalam pelaksnaan ruqyag syar'iyyah (Syamil Al-Qur'an, 2007: 215, 290, 370, 481) di antaranya adalah:

1. QS: Yusus (10) : 57

"Hai manusia, Sesungguhnya Telah datang kepadamu pelajaran dari Tuhanmu dan penyembuh bagi penyakit-penyakit (yang berada) dalam dada dan petunjuk serta rahmat bagi orang-orang yang beriman".

2. QS; Al Isra (17) : 82

"Dan kami turunkan dari Al Quran suatu yang menjadi penawar dan rahmat bagi orang-orang yang beriman".

3. QS: Asy-Syu'ara (26) : 80

"Dan apabila Aku sakit, dialah yang menyembuhkan aku,"

4. Fushishilat (41): 44

"Katakanlah: "Al Quran itu adalah petunjuk dan penawar bagi orang-orang mukmin." 
Sedangkan di antara dalil-dalil dari sunnah Nabi Saw. adalah:

1. Ruqyah yang dilakukan malaikat jibril as. Ketika datang kepada Nabi Saw. dan berkata: "Wahai Muhammad, engkau sakit?" Nabi Saw. menjawab: “Ya”. Lalu jibril membaca :

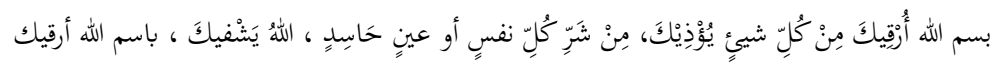

"Dengan nama Allah, aku meruqyah kamu dari segala sesuatu yang mengganggumu, dari kejahatan setiap jiwa atau mata yang dengki. Allah menyembuhkan kamu, dengan nama Allah aku meruqyah kamu". [HR. Muslim].

2. Riwayat yang disampaikan Aisyah Radhiyallahu anha bahwa Rasul Saw. mengusap orang yang sakit diantara kami dengan tangannya dan membaca:

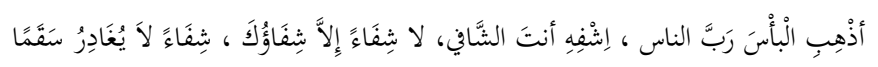

"Hilangkanlah segala penyakit, wahai Tuhan sekalian manusia. Sembuhkanlah ia, karena Engkaulah Yang Maha Menyembuhkan. Tidak ada kesembuhan kecuali kesembuhan (dari)Mu dengan kesembuhan yang tidak menyisakan sakit." [HR. Muslim].

3. Sahabat Usman bin Abu Al-'Ash mengeluh kepada Rasulullah Saw. mengenai sakit yang ia derita pada tubuhnya sejak masuk islam. Maka Rasulullah Saw. bersabda: "Letakkanlah tanganmu di bagian tubuhmu yang sakit lalu ucapkan : Bismillah tiga kali, lalu bacalah:

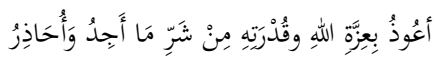

"Aku berlindung kepada keperkasaan dan kekuasaan Allah dari kejahatan apa yang aku dapati dan aku khawatirkan" (dibaca) 7 kali. [HR. Ahmad].

4. Riwayat dari Abdurrahman bin Aswad dari bapaknya berkata: "Aku bertanya kepada 'Aisyah -semoga Allahmeridhainya- tentang rukyah untuk mengobati bisa (racun pada ular atau kalajengking). Ia menjawab : "Nabi Saw. membolehkan rukyah untuk penyakit yang disebabkan oleh tiap-tiap bintang yang berbisa". [H.R. Bukhari] (Amin, 2005)

\section{Syarat-Syarat Ruqyah Syariyyah}

Al Hafizh Ibnu Hajar -rahumahullahu- (Az-Zarqaa', 2005) menjelaskan: "Para ulama telah berijma' (bersepakat) akan bolehnya menggunakan ruqyah (dalam pengobatan) dengan terpenuhinya tiga syarat:

1. Ruqyah tersebut dengan menggunakan Kalamullah (ayat-ayat Al Qur'an), atau nama-nama dan sifat Allah 'Azza wa Jalla.

2. Ruqyah tersebut harus diucapkan dengan bahasa Arab atau bahasa selain Arab yang dibaca dengan jelas dan difahami maknanya. Sebagaimana penjelasan Syaikh 
Abdurrahman Hasan Alu Syaikh dalam kitabnya "Fathul Majid", Alkhattabi berkata : "Waktu itu Rasulullah meruqyah dan diruqyah. Beliau menyuruhnya dan memperbolehkannya. Jika ruqyah itu dengan Al-Qur'an dan Asma Allah, maka itu diperbolehkan atau bahkan diperintahkan. Akan tetapi dimakruhkan jika tidak dengan bahasa arab, karena barangkali ada kalimat kufur atau syirik (Abdurrahim, 2010: 120).

3. Harus diyakini, bahwa yang memberikan pengaruh dan kesembuhan bukanlah ruqyah dengan sendirinya, tetapi yang memberi pengaruh adalah (izin dan) kekuasan Allah Azza wa Jalla.

Menurut Susanto (2014) Pada dasarnya dalam praktiknya, ruqyah yang menggunakan ayat-ayat al-Qur'an memiliki dasar asumsi bahwa ayat al-Qur'an memiliki energi yang dapat memberikan efek psikoterapi terhadap penderita yang mengalami gangguan kesehatan mental akibat kesurupan. Menurutnya psikoterapi diartikan sebagai penerapan teknik khusus pada penyembuhan penyakit mental atau pada kesulitan penyesuaian diri setiap hari, atau dapat pula mencakup suatu pembicaraan informal dengan para menteri atau duta, penyembuhan lewat keyakinan agama, dan diskusi personal dengan para guru atau teman. kegiatan pelayanan terapi ruqyah memiliki peran strategis dalam rangka mendukung upaya penyembuhan. Menurutnya ini bisa dijelaskan lewat hubungan antara sistem kekebalan tubuh pada diri seseorang dengan kesehatan psikisnya. Hubungan keduanya dalam dunia kedokteran modern, dapat diterangkan dalam sebuah cabang ilmu "psiko-neuro-imunologi" Selain tiga di atas Abdullah bin Abdul Aziz Al-Aidan (Az-Zarqaa', 2005) juga menambahkan: (1) Tidak meruqyah dengan cara yang haram atau bid'ah. Seperti meruqyah di kamar mandi, di kuburan, dan lain-lain. (2) Peruqyah bukan tukang sihir, dukun atau tukang ramal. (3) Ruqyah tidak mengandung ungkapan-ungkapan atau simbol-simbol yang diharamkan, karena Allah swt. tidak menjadikan obat pada sesuatu yang haram.

Dr. Ibrahim bin Muhammad Al-Buraikan memberikan syarat ruqyah syar'iyyah lebi terperinci. Katanya ruqyah yang dibolehkan itu memiliki beberapa syarat yaitu:

1. Hendaklah dengan membacakan ayat Alquran, nama-nama dan sifat-Nya serta doa-doa Nabi Muhammad saw.

2. Hendaklah dengan bahasa Arab.

3. Hendaklah dipahami maknanya. 
4. Tidak mengandung sedikit pun sesuatu yang tidak dibolehkan seperti meminta bantuan dan berdoa kepada selain Allah atau memanggil nama jin dan raja-raja mereka.

5. Hendaklah tidak bergantung kepada ruqyah saja.

6. Hendaklah meyakini bahwa bukan semata-mata ruqyah yang memberi pengaruh, tetapi degan izin Allah.

Jika ditinjau dari aspek pelaksanaan dan manfaatnya, ruqyah syar'iyyah dapat diklasifikasikan menjadi dua yaitu ruqyah penyembuhan da ruqyah pembentengan (Tambusai, 2010).

\section{Materi Ruqyah}

El-Quds (2006) menyebutkan bahwa Al-Qur'an merupakan obat yang sempurna buat segala macam penyakit hati dan badan, baik dunia dan akhirat. Namun tidak semua orang dianugerahi keahlian dan kemampuan melakukan pengobatan dengan Alquran. Bahkan secara umum, El-Quds (2006) menyebutkan ayat-ayat Alquran seluruhnya bisa digunakan untuk meruqyah, dan tidak dikecualikan darinya satu ayat pun. Hanya saja, beberapa ayat memang memiliki pengaruh dan efek lebih kuat dari ayat lainnya, sebagaimana yang dijelaskan oleh Rasulullah Shallallahu 'Alaihi Wasallam dalam hadis-hadisnya.

1. Al Mu'awwidzaat, yaitu surat Al Ikhlash, Al Falaq dan An Naas. Berdasarkan hadis dari 'Aisyah -radiallahu 'anha-, (Az-Zarqaa', 2005)

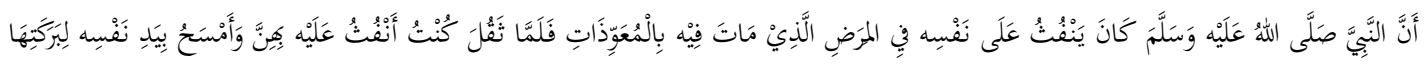

"Bahwa Nabi Shallallahu 'Alaihi Wasallam meniup untuk dirinya sendiri pada saat Beliau sakit yang mengantarkannya pada kematian, dengan membaca mu'awwidzaat, maka tatkala sakit Beliau bertambah parah, akulah yang meniupkan pada tubuh Beliau dengan membaca mu'awwidzaat tersebut dan aku mengusapkannya ke wajahnya dengan tangan Beliau sendiri karena keberkahan (tangan Beliau)"

Dan juga sabda Beliau Shallallahu 'Alaihi:

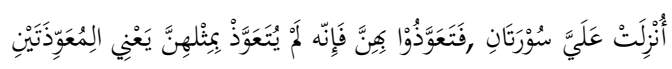

"Telah diturunkan kepadaku dua surat, yakni mu'awwidzatain, maka mohonlah perlindungan Allah dengannya, karena sesungguhnya seseorang tidak mendapat perlindungan seperti perlindungan dengan membaca dua surat ini" 
Sesungguhnya disebutkan banyak sebab turunnya dua surah ini (Al-Falaq dan An-Nas), di antaranya:

a. Bahwa Ifrit dari golongan jin, pernah berusaha mencelakai Rasulullah saw., maka Allah menurunkan mu'awwidzatain untuk menolak tipu dayanya.

b. Allah menurunkan kedua surah ini sebagai ruqyah, pengobat dari penyakit 'ain, sebagai pengganti mantera yang dipakai manusia untuk meruqyah, yang kadang mengandung kekufuran dan kesyirikan (Adham, 2009)

2. Surah Al-Fatihah

Berdasarkan hadits dari Abu Sa'id Al Khudri - radhiallahu 'anhu-,

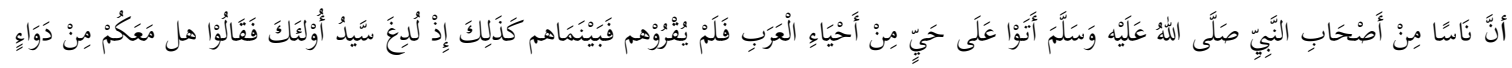

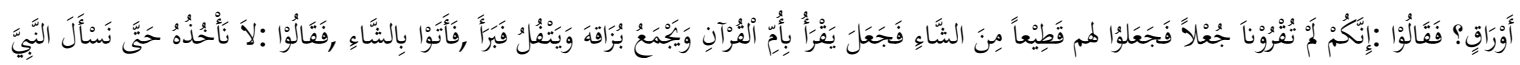

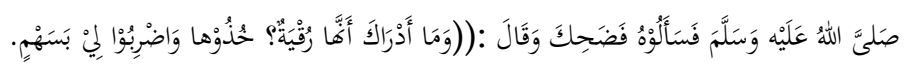

"Bahwa sekelompok sahabat Nabi pernah mengunjungi salah satu perkampungan Arab, tuan rumah daerah itu tidak mau menjamu mereka. Dalam keadaan demikian, tiba-tiba pemimpin kaum itu disengat binatang berbisa. Kaum itu berkata kepada mereka:" Apakah kalian mempunyai obat atau seorang yang bisa meruqyah? Mereka menjawab:"Sesungguhnya kalian tidak mau menjamu kami. Kami tidak akan membantu kalian sampai kalian memberi kami upah". Maka mereka pun memberikan beberapa ekor kambing. Salah seorang sahabat kemudian membaca surat Al Fatihah dan mengumpulkan air ludahnya kemudian meludahi (pemimpin yang tersengat tadi). Ia pun sembuh. Merekapun memberikan kambing. Lalu para sahabat berkata,"Kita tidak akan mengambilnya sampai kita bertanya dahulu kepada Nabi Shallallahu 'Alaihi Wasallam". Mereka bertanya kepada Nabi tentangnya. Beliaupun tertawa dan bertanya:"Apa yang membuatmu tahu bahwa (Al Fatihah) adalah ruqyah? Ambillah kambing itu dan berikanlah aku sebagiannya".

\section{Surat Al Kafirun}

Berdasarkan hadis dari Ali, ia berkata:"Seekor kalajengking pernah menyengat Nabi, sedangkan saat itu Beliau sedang shalat. Ketika Beliau selesai dari shalat, Beliau bersabda:

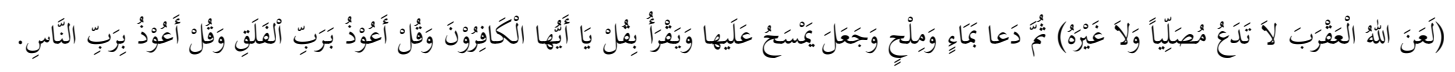

"Semoga Allah melaknat kalajengking, ia tidak membiarkan orang yang shalat maupun selainnya". Kemudian Beliau minta dibawakan air dan garam, seraya mengusapkan (di atas lukanya) dan Beliau membaca surat Al Kafirun, suarat Al Falaq dan surat An Nas." 
4. Ayat-ayat yang lain, seperti dua ayat terakhir dari surat Al Baqarah dan ayat kursi (AzZarqaa', 2005)

Adapun doa-doa dan dizikir-dzikir dari hadis Nabi Shallallahu 'Alaihi Wasallam yang dapat dibaca dalam pelaksanaan ruqyah syar'iyyah (Amin, 2005: 84-87), di antaranya adalah:

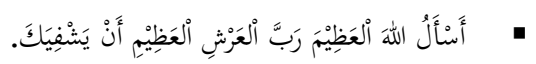

"Aku mohon kepada Allah Yang Maha Agung, Pemilik 'Arsy yang agung, agar Ia menyembuhkanmu". Doa ini dibaca tujuh kali.

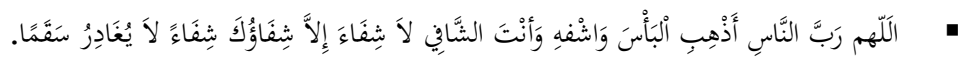

"Ya Allah Sang Pemelihara manusia, hilangkanlah penyakitnya dan sembuhkanlah, Engkaulah Yang Maha Menyembuhkan, tidak ada kesembuhan melainkan kesembuhan dari-Mu semata, kesembuhan yang tidak meninggalkan rasa sakit".

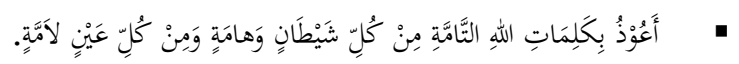

"Aku berlindung kepada Allah dengan kalimat-kalimat-Nya yang sempurna, dari setiap kejelekan setan, binatang berbisa, dan dari setiap mata yang jahat".

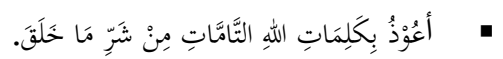

"Aku berlindung kepada Allah dengan kalimat-kalimat- Nya yang sempurna, dari setiap kejahatan makhluk-Nya".

Menurut Ahmad \& Ariffin (2014) ada beberapa faktor yang menyebabkan ayat dapat dijadikan sebagai ruqyah yaitu, ayat Al-Qur'an memiliki kalimat atau perkataan utama secara jelas yang berkaitan dengan penyakit; Selain itu pengajaran terhadap kisah dibalik penurunan ayat dan adanya pemahaman yang tersirat disebalik makna ayat al-Quran; dan Al-Qur'an memuat pengalaman dan ilmu yang dipelajari atau diwarisi daripada pengalaman orang lain.

Menurut Siregar (2016) Al Qur'an merupakan obat yang sempurna dan penawar bagi seluruh penyakit hati dan jasad, serta penyakit-penyakit dunia dan akhirat. Namun tidak semua orang mampu dan mempunyai kemampuan untuk melakukan penyembuhan dengan Al Qur'an. Jika pengobatan penyembuhan dilakukan secara baik terhadap penyakit, didasari dengan kepercayaan dan keimanan, penerimaan yang penuh, keyakinan yang pasti, serta 
terpenuhi syarat-syaratnya, maka tidak ada satu penyakit pun yang mampu melawannya selama-lamanya. Surat yang dibaca dalam Alqur'an dalam Ruqyah adalah Al Mu'awwidzaat, yaitu surat Al Ikhlash, Al Falaq dan An Naas, Surat Al Fatihah, Surat Al Kafirun dan Ayat-ayat yang lain, seperti dua ayat terakhir dari surat Al Baqarah dan ayat kursi.

\section{Tata Cara Ruqyah Yang Benar}

Tata cara ruqyah yang benar (Az-Zarqaa', 2005) adalah sebagai berikut:

1. Keyakinan bahwa kesembuhan hanya datang dari Allah Subhanahu wa Ta'ala semata, bukan dari selainNya.

2. Ruqyah harus dengan Alquran, hadis atau dengan nama dan sifat Allah, dengan bahasa Arab atau bahasa yang dapat difahami.

3. Mengikhlaskan niat dan menghadapkan diri kepada Allah saat membaca dan berdoa.

4. Membaca surat Al Fatihah dan meniup anggota tubuh yang sakit. Demikian juga dengan membaca surat Al Falaq, An Naas, Al Ikhlash, Al Kafirun.

5. Menghayati makna yang terkandung dalam bacaan Alquran dan doa yang sedang dibaca.

6. Orang yang meruqyah hendaknya memperengarkan bacaan ruqyahnya, baik yang berupa ayat-ayat Alquran atau doa-doa dari Nabi Shallallahu 'Alaihi Wasallam. Supaya penderita belajar dan merasa tenang bahwa ruqyah yang dibacakan sesuai dengan syariat.

7. Meniup pada tubuh orang yang sakit di tengah-tengah pembacaan ruqyah. Masalah ini, menurut Syaikh Al Utsaimin mengandung kelonggaran. Caranya, dengan tiupan yang lembut tanpa keluar air ludah. 'Aisyah -radhiallahu 'anha- pernah ditanya tentang tiupan Nabi Shallallahu 'Alaihi Wasallam dalam meruqyah. Ia menjawab:"Seperti tiupan orang yang makan kismis, tidak ada air ludahnya (yang keluar)". (H.R Muslim 14/182). Atau tiupan tersebut disertai keluarnya sedikit air ludah sebagaimana dijelaskan dalam hadis 'Alaqah bin Shahhar As Salithi, tatkala ia meruqyah seseorang yang gila, ia mengatakan:"Maka aku membacakan Al Fatihah padanya selama tiga hari, pagi dan sore. Setiap kali aku menyelesaikan bacaanku, aku kumpulkan air liurku dan aku ludahkan. Maka dia seolah-olah lepas dari sebuah ikatan". (H.R Abu Daud 4/3901 dan Al Fathu Ar Rabbani, 17/184) 
8. Jika meniupkan ke dalam media berisi air atau selainnya, tidak masalah. Media terbaik untuk ditiup adalah minyak zaitun atau air hujan. Berdasarkan hadis dari Malik bin Rabi'ah, bahwa Rasulullah Shallallahu 'Alaihi Wasallam bersabda:

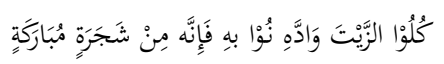

"Makanlah minyak Zaitun, dan olesilah tubuh kalian dengannya. Sebab ia berasal dari tumbuhan yang penuh berkah".

Dan firman Allah Ta'ala:

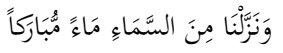

"Dan Kami turunkan dari langit air yang banyak manfa'atnya" (Q.S Qaaf: 9).

9. Mengusap orang yang sakit dengan tangan kanan. Ini berdasarkan hadits 'Aisyah radhiallhu 'anha- ia berkata:"Rasulullah tatkala dihadapkan pada seseorang yang mengeluh kesakitan, Beliau mengusapnya dengan tangan kanan...."(H.R Muslim, Syarah An Nawawi (14/180). Imam An Nawawi berkata:"Dalam hadits ini terdapat anjuran untuk mengusap orang yang sakit dengan tangan kanan dan mendoakannya. Banyak riwayat shahih tentang hal itu, aku telah menghimpunnya dalam kitab Al Adzkar". Dan menurut Syaikh Al Utsaimin, tindakan yang dilakukan sebagian orang saat meruqyah dengan telepak tangan orang yang sakit atau anggota tubuh tertentu untuk dibacakan kepadanya, maka tidak ada dasarnya sama sekali".

10. Bagi orang yang meruqyah diri sendiri, letakkan tangan di bagian yang dikeluhkan sambil membaca \{ بسم اللّ $\}$ tiga kali, kemudian membaca:

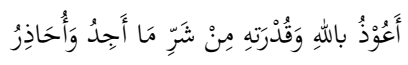

"Aku berlindung kepada Allah dan kekuasaanNya dari setiap kejelekan yang aku jumpai dan aku takuti".

Dalam riwayat lain disebutkan "dalam setiap usapan" Doa itu diulangi sebanyak tujuh kali. Atau membaca :

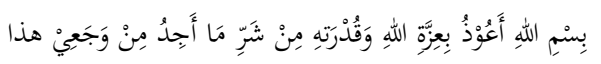
"Dengan menyebut nama Allah, aku berlindung kepada keperkasaan Allah dan kekuasaanNya dari setiap kejelekan yang aku jumpai dari rasa sakitku ini". 
11. Apabila rasa sakit terdapat diseluruh tubuh, caranya dengan meniup dua telapak tangan dan mengusapkannya ke wajah si sakit dengan keduanya. Bila penyakit terdapat di salah satu bagian tubuh, kepala, kaki, atau tangan misalnya, maka dibacakan pada tempat tersebut. Disebut dalam hadis, Muhammad bin Hathib Al Jumahi dari ibunya, Ummu Jamil binti Al Jalal, ia berkata:" Aku datang bersamamu dari Habasyah. Tatkala engkau telah sampai di Madinah semalam atau dua malam, aku hendak memasak untukmu, tetapi kayu bakar habis. Aku pun keluar untuk mencarinya. Kemudian bejana tersentuh tanganku dan berguling menimpa lenganmu. Maka aku membawamu ke hadapan nabi. Aku berkata: "Kupertaruhkan engkau dengan ayah dan ibuku, wahai Rasulullah, ini Muhammad bin Hathib". Beliau meludah di mulutmu dan mengusap kepalamu serta mendoakanmu. Beliau masih meludahi kedua tanganmu dan membaca doa:

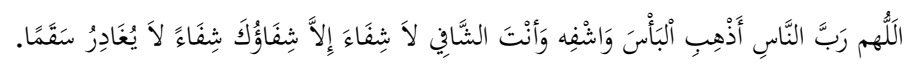

12. Apabila penyakit ada disekujur badan, atau lokasinya tidak jelas, seperti gila, dada sempit atau keluhan pada mata, maka cara mengobatinya dengan membacakan ruqyah di hadapan si penderita. Dalam sebuah riwayat disebutkan bahwa Nabi meruqyah orang yang mengeluhkan rasa sakit. Disebutkan dalam riwayat Ibnu majah, dari Ubay bin Ka'ab, ia berkata: "Maka tatkala ia didudukkan dihadapan Beliau. Kemudian aku mendengar Beliau membentenginya dengan surat Al Fatihah".

Menurut Alawiyah \& Handayani (2019) diketahui bahwa jika dilihat dari pandangan sikoterapi maka ruqyah ini merupakan proses terapi yang sebenarnya memiliki tujuan dasar yang ingin dicapai yakni ketenangan jiwa dan pemenuhan kebermaknaan hidup melalui pendidikan spiritual. Nilai spiritual terletak pada kerahasiaan, manusia tidak tahu apakah salatnya diterima atau tidak, apakah puasanya berkualitas dihadapan Allah atau tidak. Proses bimbingan spiritual yang dilakukan melalui bimbingan konseling pribadi dan sosial, selalu memberikan layanan konsultasi untuk memberikan dukungan sosial dan empati.

Proses terapi ruqyah sya'iyyah, selain dengan membaca doa-doa dari Al-Qur'an dan Al-Hadist maka diperlukan juga pemberian nasehat, penerimaan diri dan melakukan 
amalan-amalan ibadah seperti sholat,dzikir, membaca Al-Qur'an dan amalan-amalan ibadah lainnya (Jayanti dkk., 2019). Menurut Mu'alifah (2018) Pelaksanaan sesuai dengan syari'at Islam yaitu memakai Kalamullah (Alquran), sifat-sifat Allah, dan doa-doa yang ma'tsur; diucapkan dengan kalimat yang jelas dan mudah dimengerti; tidak adanya kesyirikan (meminta bantuan jin); dan mempasrahkannya hanya kepada Allah SWT. Adapun jenis gangguan yang ditangani menggunakan ruqyah syar'iyyah adalah gangguan fisik dan psikis. Terdapat metode lain yang digunakan saat proses meruqyah yaitu konseling, kanalisasi emosi, dan parts therapy.

\section{Faktor Utama Keberhasilan Ruqyah}

Dalam pengobatan dengan cara ruqyah syar'iyyah tidak ada jaminan kesembuhan secara cepat atau dengan beberapa kali diruqyah. Kadang ada yag sekali ruqyah sudah sembuh, dan ada pula yang sampai berkali-kali bahkan hitungan tahun baru membaik. Oleh karena itu perlu keikhlasan dan kesabaran, jangan sampai mengambil jalan pintas yang diharamkan, sebab penyembuhan dengan ruqyah syar'iyyah tidak selalu bersifat instan dan cepat menampakkan hasil seketika, apalagi penyakitnya murni medis. Oleh karena itu, setiap peruqyah maupun pasien yang diruqyah harus memahami dan meyakini adanya faktor-faktor

yang menentukan sembuh tidaknya seseorang dengan terapi ruqyah syar'iyyah. Adapun foktor-faktor utama keberhasilan ruqyah itu antara lain adalah:

1. Izin dan kehendak Allah. Faktor utama ini merupakan kunci yang tidak dapat diprediksi dan diupayakan oleh siapa pun. Oleh karenanya, baik peruqyah dan pasien tidak dapat memaksakan keinginan untuk sembuh.

2. Keikhlasan peruqyah dan orang yang diruqyah. Ini juga merupakan faktor kunci yang memberikan pengaruh besar untuk mendapatkan kesembuhan. Ikhlas tidak hanya diartikan "tanpa pamrih", Walaupun itu merupakan satu sisi makna ikhlas. Karena ikhlas tidak dapat diukur oleh manusia, maka manusia hanya dituntut menghadirkan suasana, kondisi, cara dan media untuk mengoptimalkan lahirnya keikhlasan itu.

3. Ketakwaan serta kesalehan orang yang meruqyah. 
4. Pengalaman dan keahlian peruqyah. Faktor juga penting karena banyak peruqyahperuqyah pemula yang hanya bermodalkan suara dan keberanian ternyata tidak mampu mengatasi persoalan di "medan laga".

5. Usaha dari pasien sendiri dalam memperbaiki diri dan melakukan pembentengan dengan memperbanyak ibadah dan doa-doa serta zikir.

6. Tempat pelaksanaan atau proses ruqyah harus sesuai standar syar'i. Faktor ini banyak yang tidak disadari oleh pasien dan keluarganya, jika pelaksanaan ruqyah itu berlangsung di rumah atau tempat tinggal pasien.

7. Kesiapan pasien untuk merunah prinsip dan sikap, dari malas ibadah menjadi giat ibadah, dari tidakmemahami Islam menjadi penuh semangatmengkaji Islam dan mengamalkannya. (Tambusai, 2010)

\section{Penyimpangan dalam Praktik ruqyah}

Dalam pelaksanaan ruqyah syar'iyyah sejatinya tidak dicampuri dengan perilaku yang berbenturan dengan ruqyah yang sebenarnya. Andaikata ada diharuskan dan inovasi dalam pengembangan ruqyah syar'iyyah tetapi harus tetap mengacu kepada tuntunan Alquran dan hadis. Namun dalam kenyataannya banyak praktik ruqyah yang dianggap tidak sesuai dengan ruqyah sya'iyyah yang sejati.

Dalam buku “ Menguak Dunia Jin “RUQYAH” Dampak dan Bahayanya” oleh Lutfi Ghozali disebutkan bahwa: Ruqyah dewasa ini sering bukan mengeluarkan jin dari tubuh manusia, tetapi justru membantu memasukan jin untuk menguasai kesadaran manusia. Sebenarnya Ruqyah Syariyyah hanya digunakan untuk orang yang sakit (bermasalah). Ruqyah tidak digunakan kepada orang sehat wal afiat dan sadar. Permasalahan yang sering terjadi adalah pelaksanaan "ruqyah" yang mana ketika orang yang asalnya sadar hanya kuatir barangkali ada jin di dalam tubuhnya, dengan tanda-tanda yang kesannya dibuat-buat sebagaimana yang diajarkan. Maka kesadarannya sering dipertaruhkan, sehingga mereka minta diruqyah, dan ketika diruqyah mereka menjadi tidak sadarkan diri bahkan ada yang muntah-muntah dan terkencing di tempat. Mengapa yang demikian dikatakan mengeluarkan jin dari dalam tubuh manusia? Seharusnya yang dikatakan mengeluarkan jin itu adalah 
mengeluarkan jin dari wilayah kesadaran manusia yang sudah terlanjur dikuasai jin, yaitu ketika manusia sedang hilang ingatan, gila, kesurupan dan penyakit akibat gangguan jin, setelah dibacakan ayat suci Alquran kemudian menjadi sadar seperti semula. Bukannya dibacakan ayat-ayat Alquran orang yang asalnya sadar menjadi tidak sadarkan diri, seperti kesurupan, stres dll.

Barangkali banyak kalangan kurang memahami, sesungguhnya makhluk jin itu dapat bebas ke luar masuk dalam tubuh manusia. Mereka ke luar masuk dalam rangka memberi informasi, tipu daya melalui hati manusia bahkan bisa menganggu meyakiti fisik manusia maupun gangguan kepada psikis atau kejiwaan manusia sehingga stres, gila, kerasukan jin yang tidak sadarkan diri. Seharusnya orang yang tidak sadarkan diri itu yang diruqyah agar menjadi sadar, bukan malah sebaliknya. Orang yang sedang sakit akibat gangguan jin, diruqyah menjadi sembuh, bukan yang sembuh malah menjadi terluka akibat tusukan jin pada wilayah kesadarannya yang bahkan bisa kadang-kadang berakibat sakit yang berkepanjangan.

Justru itu patut direnungkan lagi tentang kegiatan ruqyah yang melembaga selama ini. Bukankah yang diruqyah adalah orang yang sadar kemudian menjadi tidak sadar ?. Ketika tidak sadar, maka para pelaksanaan ruqyah tersebut bersusah payah mengeluarkan jin yang terlanjur menguasai kesadaran itu, bahkan dengan tenaga dalam (katanya) sampai-sampai mengeluarkan keringat segala. Kalau yang asalnya sadar kemudian menjadi tidak sadar dan kemudian disadarkan lagi, bukankah yang demikian itu berarti memasukkan jin ?. Inilah pokok pembahasan yang paling utama.

Sebenarnya saat itu manusia secara tidak disadarinya telah mengundang jin untuk menguasai kesadarannya sendiri. Berarti manusia tanpa sadar telah melukai alat atau sarana penunjang kehidupannya yang paling vital yaitu akal. Tanpa akal manusia menjadi gila. Akibatnya, jin akan dapat dengan mudah menguasai kembali kesadaran manusia, teruatama ketika pikirannya tidak mampu menanggung beban.

Luka pada wilayah kesadaran manusia akibat kerasukan jin akan membekas selamanya. Orang tersebut akan menjadi orang yang dalam hidupnya pernah hilang ingatannya atau gila, walaupun hanya sebentar. Siapapun yang menyaksikan hal tersebut cepat sadar, bahwa hal itu merupakan aib besar bagi kesucian asal usul /silsilah garis keturunannya. Siapa yang tidak 
malu menjadi keturunan orang yang pernah gila atau pernah hilang ingatan,..? Ibarat gelas kaca, ketika sudah terlanjur pecah, sempurna apapun orang dapat menyambungnya kembali, bekas pecah itu selamanya tetap kelihatan. Demikian pula wilayah kesadaran manusia, luka itu akan membekas untuk selamanya. Yang paling berbahaya, ketika suatu saat rasio manusia terpaksa harus mananggung beban yang berat, misalnya menghadapi musibah sehingga orang harus memeras akal untuk mencari solusi dari masalah yang sedang dihadapi. Bila wilayah rasional itu pernah luka maka lukanya itu akan mudah kambuh lagi, paling tidak kekuatan dan daya tahannya pasti akan berkurang. Kalau hal itu akibat perbuatan yang disengaja,berarti manusia dengan sengaja telah berbuat kebodohan dengan merusak diri sendiri bahkan kesucian garis keturunannya, Ironisnya sarana untuk merusak kesadaran manusia itu adalah ayat-ayat suci Alquran yang semestinya adalah obat penyembuh kesadaran.

Apabila orang yang sehat dan sadar diruqyah kemudian dia kesurupan dan tidak sadarkan diri, kalau dia meninggal dunia saat itu, tentu dia lupa Allah, tidak mampu berzikir di penghujung hayatnya, tentu alangkah besarnya dosa si peruqyah itu. Hal ini pernah penulis saksikan di saat seseorang kesurupan kemudian meninggal dunia.

\section{Kesimpulan}

Ruqyah Syar'iyyah adalah pengobatan islami yang menggunakan bacaan ayat-ayat suci Alquran, zikir da doa. Penyakit yang bisa disembuhkan lewat ruqyah syar'iyyah dengan izin Allah adalah penyakit lahir maupun penyakit batin atau penyakit jasmani atau rohani, dengan istilah lain adalah penyakit fisik ataupun psikis. Dasar adanya penyembuhan secara islami ini terdapat dalam Alquran dan hadis nabi. Walaupun ada dasarnya, tapi bagi pasien penderita hukumnya minta diruqyah hanya mubah, sedangkan peruqyah sunat hukumnya menolong orang yang minta tolong dengan tanpa mengharap imbahalan berupa upah. Para ulama sepakat penggunaan ruqyah ini dengan ayat suci Alquran dan yakin bahwa manusia hanya sebagai perantara, masalah kesembuhan adanya izin dari Allah swt. Rasulullah mempraktikan tiga jenis pengobatan ilahiyah yaitu Ruqyah Sayar'iyyah, Thabi'iyyah (seperti mengkunsumsi madu, kurma, habbatus sauda') dan Al-Jam'u baina huma (mengkombinasikan keduanya). Ketiganya ini dirangkum dalam satu sistem yang disebut Thibbun Nabawi. Ruqyah 
ini dengan izin Allah membuat orang yang sakit menjadi sehat, atau orang yang asalnya tidak sadarkan diri menjadi sadar. Dulu di daerah ini dkenal dengan istilah batatamba yaitu mengobati penyakit kepada tabib yang menggunakan ayat suci Alquran, zikir dan doa.

Para ulama telah berijma' (bersepakat) akan bolehnya menggunakan ruqyah (dalam pengobatan) dengan terpenuhinya tiga syarat:

1. Ruqyah tersebut dengan menggunakan Kalamullah (ayat-ayat Al Qur'an), atau nama-nama dan sifat Allah 'Azza wa Jalla.

2. Ruqyah tersebut harus diucapkan dengan bahasa Arab atau bahasa yang dapat difahami maknanya.

3. Harus diyakini, bahwa yang memberikan pengaruh dan kesembuhan adalah atas kekuasaan Allah Azza wa Jalla.

Saran

Itulah ruqyah syar'iyah. Tidak seperti anggapan sebagian orang bahwa ruqyah adalah sejenis sihir, mantra, jampi atau bid'ah yang tidak memiliki dasar dalam agama Islam. Dewasa ini ruqyah banyak di pragakan atau dipraktikan di TV, Youtube serta di tempat-tempat tertentu yang melayani pengobatan secara resmi. Di samping ruqyah untuk orang yang sakit, juga dalam kenyataan ada orang yang sehat, dalam keadaan sadar dan menduga dalam dirinya ada jin sehingga dia minta diruqyah. Pada akhirnya dia tidak sadarkan diri semacam kerasukan mahluk halus, bahkan ada yang sampai muntah-muntah dan terkencing-kencing setelah dibacakan bacaan ruqyah oleh peruqyah. Keadaan ini berbenturan dengan tujuan ruqyah yang untuk menyembuhkan orang yang sakit atau menyadarkan orang yang tidak sadarkan diri. Dengan mengetahui tata cara pelaksanaan ruqyah syar'iyyah yang tepat maka pembaca dapat memilah-milah mana tempat praktik ruqyah yang sesuai syar'i yang sesuai dengan tuntunan agama dan dapat menghindari praktik penyembuhan yang bertentangan dengan akidah. Peneliti selanjutnya dapat menjadikan hasil kajian ini sebagai bahan atau referensi utama untuk penelitian selanjutnya yang terkait dengan ruqyah sebagai alternatif psikoterapi, misalnya mengukur keberhasilan terapi dengan ruqyah syar'iyah ataupun mendeskripsikan fenomena ruqyah syar'iyyah yang terjadi di masyarakat 


\section{Referensi}

Abdurrahim, N. bin M. (2010). Inilah Jampi-Jampi (Ruqyah) Yang Diajarkan Rasulullah SAW. Cakrawala Insani.

Adham, I. K. (2009). Kupas Tuntas Masalah Jin dan Sihir. Darus Sunah Press.

Afiyatin, A. L. (2019). Ruqyah Sebagai Pengobatan Berbasis Spiritual Untuk Mengatasi Kesurupan. Hisbah: Jurnal Bimbingan Konseling dan Dakwah Islam, 16(2), 216-226.

Ahmad, K., \& Ariffin, M. F. M. (2014). Terapi Ruqyah Berasaskan Al-Quran: Analisis Signifikannya Dalam Rawatan Penyakit. 14-15.

Alawiyah, D., \& Handayani, I. (2019). Penanaman Nilai Spiritual dalam Dimensi Psikoterapi Islam di PP. Rehabilitasi Salafiyah Syafi'iyah Nashrun Minallah. KONSELI: Jurnal Bimbingan dan Konseling (E-Journal), 6(1), 23-32.

Arikunto, S. (2010). Metode peneltian. Rineka Cipta.

Az-Zarqaa', U. A. H. (2005). Terapi Pengobatan dengan Ruqyah Syar'iyah. Pustaka El-Posowy.

El-Quds, M. S. (2006). Pengobatan Dengan Al-Qur'an. Amelia.

Ibnu Qayyim Al-Jauziyah. (2013). Buku Pintar Kedokteran Nabi. PT Fathan Prima Media.

Jayanti, A. M., Nashori, F., \& Rumiani, R. (2019). Terapi Ruqyah Syar'iyyah Meningkatkan Kebahagiaan Perempuan Korban Kekerasan Dalam Rumah Tangga. JIP (Jurnal Intervensi Psikologi), 11(2), 111-122.

Manan, I. A. (1991). Berbagai Masalah Tauhid Populer jilid I. PT. Bina Ilmu.

Mu'alifah, F. (2018). Terapi ruqyah syar'iyyah di Klinik Griya Sehat Syafaat 99 Semarang. UIN Walisongo Semarang.

Siregar, P. (2016). Psikoterapi Islam Dalam Mengatasi Depresi. Hikmah, 10(2).

Sugiyono. (2010). Metode penelitian kuantitatif dan RED. Alfabeta.

Susanto, D. (2014). Dakwah Melalui Layanan Psikoterapi Ruqyah bagi Pasien Penderita Kesurupan. Konseling Religi: Jurnal Bimbingan Konseling Islam, 5(2), 313-334.

Tambusai, M. B. (2010). Buku Pintar Jin, Setan dan Ruqyah Syariyyah. Pustaka Al Kautsar.

Tambusai, M. B. (2013). Halal-Haram Ruqyah: Tuntunan Syariah Mengatasi Sihir, Gangguan Jin dan Berbagai Penyakit Rohani dan Jasmani. Pustaka Al-Kautsar.

Tutut, I. P. (2020). Metode Ruqyah Dalam Pemulihan Pasien Skizofrenia (Studi Pada Yayasan Aulia Rahma Rehabilitasi Gangguan Jiwa Di Kemiling Bandar Lampung) [Disertasi]. Universitas Raden Intan. 


\begin{tabular}{|l|l|l|l|l|}
\hline Submit & Review & Revisi & Diterima & Publis \\
\hline 02-09-2020 & $05-10-2020$ sd 24-04-2021 & 02-05-2021 & $08-05-2020$ & $08-06-2021$ \\
\hline
\end{tabular}

Arni

Universitas Islam Negeri (UIN) Antasari Banjarmasin

Email : arnidaily@gmail.com 